\title{
Peningkatan Kebugaran Jasmani Melalui Latihan Cross Country Mahasiswa UKM Karate Dimasa Pandemi Covid 19
}

\section{Improvement Of Physical Fitness Through Cross Country Exercise Karate Student Activity Unit During Covid 19 Pandemic}

\author{
Oman Hadiana ${ }^{*}$, Sartono ${ }^{2}$ \\ 1,2Pendidikan Jasmani Kesehatan dan Rekreasi, STKIP Muhammadiyah Kuningan, Indonesia \\ email: hadianaoman@upmkc.ac.id11 , satria_bms@upmk.ac.id² \\ doi: $:$ https://doi.org/10.20884/1.paju.2021.3.1.4460
}

\begin{abstract}
Abstrak
Penelitian ini dilatarbelakangi oleh tingkat kebugaran jasmani mahasiswa yang rendah selama masa pandemi covid 19. Tujuan penelitian adalah untuk meningkatkan derajat kebugaran jasmanif mahasiswa UKM Karate dengan menerapkan latihan crosss country. Metode yang digunakan adalah eksperimen dengan desain one group pretest-posttest design. Sampel penelitian adalah mahasiswa UKM Karate STKIP Muhammadiyah Kuningan yang berjumlah 36 orang, 20 laki-laki dan 16 perrempuan. Instrumen untuk mengukur kebugaran jasmani menggunakan tes lari 2,4 Km. Hasil perolehan pretest dan posttest kebugaran jasmani mahasiswa UKM Karate STKIP Muhammadiyah Kuningan diperoleh rata-rata nilai pretest sebesar 16.58, nilai tertinggi 19, nilai terendah sebesar 15, dan standar deviasi 0.97 . Untuk nilai rata-rata posttest adalah 18.19, nilai tertinggi 20 , nilai terrendah 16 , dan standar deviasi 1.06. Rata-rata tingkat kebugaran jasmani mahasiswa putra hasil pretest 50 kategori cukup, dan hasil posttest sebsesar 53,8 kategori baik. Sedangkan rata-rata tingkat kebugaran jasmani amahasiswa putri pretest 39,1 kategori cukup, dan hasil posttest sebsesar 43,5 kategori baik. Hasil pengujian paired sample tes diketahui bahwa nilai sig. (2-tailed) sebesar $0.00<0.05$, terdapat perbedaan yang signifikan antara hasil tingkat kebugaran jasmani pada data pretest dan posttest, sehingga penerapan program latihan crosss country memberikan kontribusi dalam rangka meningkatkan kebugaran jasmani mahasiswa UKM Karate STKIP Muhammadiyah Kuningan.
\end{abstract}

Kata Kunci: Croos Country, Karate, Kebugaran Jasmani, Unit Kegiatan Mahasiswa

\begin{abstract}
This research was motivated by the low level of physical fitness of students during the covid 19 pandemic. The purpose of the study was to increase the degree of physical fitness of Karate UKM students by implementing crossscountry exercises. The method used is an experiment with a one group pretestposttest design. The research sample was the students of UKM Karate STKIP
\end{abstract}

Alamat Koresponden: Pendidikan Jasmani Kesehatan dan Rekreasi, STKIP Muhammadiyah Kuningan

Email: hadianaoman@upmkc.ac.id

(c) (i)

Jurnal Physical Activity Journal (PAJU) This work is licensed under a Creative Commons Attribution

$\underline{4.0 \text { International License. }}$ 
Muhammadiyah Kuningan, amounting to 36 people, 20 men and 16 women. The instrument for measuring physical fitness uses a $2.4 \mathrm{Km}$ running test. The results of the pretest and posttest results of physical fitness students of UKM Karate STKIP Muhammadiyah Kuningan obtained an average pretest score of 16.58 , the highest score was 19, the lowest score was 15, and the standard deviation was 0.97 . The posttest mean score is 18.19 , the highest score is 20 , the lowest score is 16, and the standard deviation is 1.06. The average level of physical fitness of male students, the results of the pretest were 50 sufficient categories, and the posttest results were 53.8 in the good category. Meanwhile, the average level of physical fitness of female students in the pretest was 39.1 in the sufficient category, and the posttest results in 43.5 in the good category. The results of the paired sample test show that the value of sig. (2-tailed) of $0.00<0.05$, there is a significant difference between the results of the level of physical fitness in the pretest and posttest data, so that the application of crosss-country training programs contributes to improving the physical fitness of students of Karate UKM STKIP Muhammadiyah Kuningan.

Keywords: Croos Country, Karate, Physical Fitness, Student Activity Unit

\section{PENDAHULUAN}

Kebugaran merupakan faktor penting bagi seseorang untuk tetap sehat dan memiliki tingkat imunitas tubuh yang baik (Amalia et al., 2020; Suhartoyo et al., 2019). Dengan tingkat imunitas yang baik, seseorang akan terhindar dari penyakit ataupun lebih cepat proses pemulihan ketika mengalami sakit. Hadirnya Pandemi Covid-19 memberikan ancaman kesehatan bagi masyarakat dunia. Untuk itu, warga masyarakat dihimbau memperhatikan protokol kesehatan, menjaga imunitas tubuh, dan tetap berdoa (Aida, 2020). Dengan demikian, imunitas tubuh sangat penting menghadapi adanya Pandemi Covid-19 saat ini. Imunitas tubuh yang baik dibutuhkan seluruh lapisan masyarakat. Terlebih bagi para tenaga medis, tenaga pendidikan, dan lainnya yang rentan terhadap penularan Virus Covid-19. Meskipun anjuran kegiatan dengan pola new normal telah ada (Gumantan, et al., 2020; Setiyawan, Kresnapati, \& Setiawan, 2020; Supriyadi, \& Dupri, 2020).

Selama Pandemi Covid-19, seluruh kegiatan pembelajaran dilaksanakan secara daring termasuk di dalamnya adalah pelaksanaan perkuliahan daring. Fenomena stres hadir selama pembelajaran daring (Jatira \& Neviyarni, 2021; Mylsidayu, 2021). Perkuliahan secara daring memberikan waktu berlebih bagi mahasiswa untuk tidak bergerak aktif karena frekuensi kegiatan yang lebih banyak untuk teleconference maupun kegiatan online lainnya yang melibatkan kinerja fisik rendah. Hal ini jika diabaikan akan mengakibatkan kurangnya aktivitas fisik yang berdampak bagi tingkat kebugaran yang nantinya 
Oman Hadiana \& Sartono | Peningkatan Kebugaran Jasmani Mahasiswa UKM Karate STKIP Muhammadiyah Kuningan dimasa Pandemi Covis 19

berpengaruh terhadap imunitas tubuh. Kebugaran yang baik akan meningkatkan imunitas tubuh mahasiswa (Pratiwi, 2018). Untuk itu, seharusnya diperhatikan bagi mahasiswa untuk tetap memantau tingkat kebugarannya. Kebugaran jasmani dapat dipantau dengan melakukan tes kebugaran, bisa dengan cooper test, beep test, maupun Tes Kebugaran Jasmani Indonesia (TKJI). Pembelajaran pendidikan jasmani memiliki peran untuk dapat memantau kebugaran jasmani peserta didik (siswa/mahasiswa) selama Pandemi Covid-19 (Budi, 2015; Juniardi, Atiq, \& Purnomo, 2016; Herlina \& Suherman, 2020).

Kebugaran jasmani merupakan faktor utama yang mempengaruhi status kesehatan setiap individu (Lipecki \& Rutowicz, 2015). Secara sederhana, kebugaran jasmani dapat dipahami sebagai kemampuan seseorang dalam melakukan suatu tugas gerak tertentu secara maksimal dan efisien tanpa mengalami kelelahan yang berlebihan serta terhindar dari resiko gangguan kesehatan (Bile \& Suharjana, 2019). Pada masa pandemi COVID-19, usaha pemeliharaan kebugaran jasmani perlu untuk tetap dilakukan sebagai salah satu tindakan preventif dalam rangka meningkatkan imunitas tubuh secara khusus serta pemeliharaan kesehatan secara umum (Hale et al., 2018). Tidak dapat dipungkiri bahwa resiko penerapan belajar dari rumah selama pandemi COVID-19 telah banyak berdampak pada kurangnya intensitas aktivitas fisik pelajar pada umumnya tidak terkecuali mahasiswa. Kemudahan dalam melakukan akses informasi materi pembelajaran secara online melalui media smartphone, komputer dan media elektronik lainnya secara tidak langsung berimplikasi pada kondisi rendahnya kinerja aktivitas fisik. Kondisi ini dapat menimbulkan kecenderungan pola hidup sedentary yang akan meningkatkan resiko mengalami gangguan kesehatan seperti obesitas, gangguan pada sistem kardiovaskular, berkurangnya imunitas tubuh serta penyakit degeneratif lainnya (Knaeps et al., 2016) yang akan mengakibatkan kondisi rentan terserang virus COVID-19.

Persoalan ketidakaktifan fisik hingga kini masih menjadi masalah yang kian meluas dengan lebih dari $30 \%$ orang dewasa gagal memenuhi tingkat aktivitas fisik yang memadai (Bachmann et al., 2015). Kondisi ini mengindikasikan bahwa, akumulasi aktivitas fisik dalam sehari melalui pekerjaan rutin ternyata belum cukup untuk menunjang kebugaran jasmani secara umum. Dengan demikian maka dibutuhkan program rutin aktivitas latihan atau olahraga yang dilaksanakan secara sistematis dan bersifat kontinyu (Irianto, 2017) guna menunjang pemeliharaan kondisi kebugaran fisik (Bile \& Suharjana, 2019). Upaya pemeliharaan kebugaran jasmani di masa pandemi COVID-19 ini, selain menerapkan 
protokol kesehatan terkait COVID-19 sesuai yang dianjurkan oleh Pemerintah seperti mencuci tangan pakai sabun, memakai masker, hindari kerumunan serta menjaga jarak, juga diperlukan adanya usaha preventif lainnya untuk megantisipasi resiko penularan COVID-19 dikalangan mahasiswa.

Dalam konteks upaya memerangi penyebaran dan penularan COVID-19, lembaga pendidikan tinggi melalui program tri dharma, perlu melakukan usaha konkret untuk membantu meminimalisir resiko gangguan kesehatan sebagai dampak pandemi COVID-19 di kalangan pelajar. Usaha pemeliharaan kebugaran jasmani mahasiswa melalui program latihan olahraga mandiri di rumah dapat menjadi solusi praktis yang bermanfaat untuk pemeliharaan kondisi fisik. Pemeliharaan kondisi fisik hanya bisa dilakukan dengan membiasakan pola hidup aktif melalui aktivitas latihan atau olahraga. Program olahraga mandiri di masa pandemi COVID-19 perlu diarahkan pada tujuan untuk pemeliharaan kebugaran jasmani yang berkaitan dengan kesehatan (health related physical fitness). Komponen utama yang harus menjadi sasaran latihan kebugaran adalah kesehatan kardiovaskular, kekuatan dan daya tahan otot serta kelentukan.

Merujuk pada pengaruh serangan virus COVID-19 yang dapat melemahkan sistim imun tubuh maka dipandang perlu untuk melakukan upaya pemeliharaan dan peningkatan imunitas tubuh melalui latihan fisik yang adekuat agar menjaga kekuatan dan daya tahan tubuh tetap dalam kondisi optimal (Tapo \& Bile, 2020). Selain menunjang pemeliharaan kebugaran jasmani, latihan fisik yang adekuat juga berkontribusi penting dalam kinerja kognitif seseorang (Kim et al., 2020). Untuk itu, usaha pemeliharaan kebugaran jasmani melalui aktivitas latihan fisik, perlu dilakukan secara teratur dan berkesinambungan sehingga dapat memberikan manfaat jangka panjang yang lebih maksimal.

Aktivitas latihan kebugaran dapat dilakukan dengan berbagai cara, salah satu diantaranya adalah dengan menggunakan latihan crosss county untuk mahasiswa yang tergabung dalam Unit Kegiatan Mahasiswa (UKM) Karate STKIP Muhammadiyah Kuningan. Latihan crosss country merupakan salah satu bentuk aktivitas latihan fisik yang dilakukan di alam terbuka dimana ada bukit-bukit, belukar, selokan-selokan untuk dilompati, tanah berpasir, tanah rumput, tanah lembek, dan sebagainya, yang maksudnya adalah bukandi alam yang tanahnya rata dan yang pemandangannya membosankan (Harsono, 2012). Diharapkan dengan dilakukannya program kebugaran ini mahasiswa 
Oman Hadiana \& Sartono | Peningkatan Kebugaran Jasmani Mahasiswa UKM Karate STKIP Muhammadiyah Kuningan dimasa Pandemi Covis 19

berupaya untuk meningkatkan derajat kesehatan dinasmis, sehingga imunitas tubuh tetap terpelihara terhindar dari berbagai penyakit termasuk virus covid 19.

\section{METODE}

Metode penelitian yang penulis lakukan adalah eksperimen, adapun rancangan penelitian menggunakan one group pretest-posttest design (Sugiyono, 2013). Konstelasi desain dapat dilihat pada tabel di bawah ini.

Tabel 1. Desain penelitian

\begin{tabular}{lll}
\hline 01 & $\mathrm{X}$ & 02
\end{tabular}

Semua subyek penelitian melakukan tes awal (pretest) terlebih dahulu tentang status kebugaran jasmaninya. Perlakuan yang diberikan adalah bentuk latihan crosss country sebanyak 16 kali masing masing mahasiswa. Setelah treatmen dilakukan, subyek diukur kembali (posttest) tingkat kebugaran jasmaninya. Treatment dilakukan di alam terbuka masing-masing kediaman mahasiswa selama 16 kali pertemuan, yakni mulai dari tanggal 1 Maret sampai dengan 3 Mei. Treatment dilaksanakan satu mingu tiga kali, yaitu hari Senin, Rabu, dan Hari Jumat. Jumlah seseluruhan mahasiswa yang tergabung dalam UKM karate sebanyak 36 orang, adapun sampel penelitian seluruh jumlah populasi yaitu 36 orang. Teknik pengambilan sampel adalah total sampling (Sugiyono, 2013).

Penulis menerapkan program latihan crosss country untuk meningkatkan kebugaran jasmani mahasiswa yang tergabung dalam Unit Kegiatan Mahasiswa (UKM) karate STKIP Muhammadiyah Kuningan. Karena di masa pandemi, prosedur yang dilakukan adalah memberikan program latihan berupa soft file secara daring melalui (zoom meeting, e-mail, dan whatsapp). Mahaiswa mendownload file berupa program latihan cross country tersebut untuk dilaksanakan selama 16 kali latihan. lintasan jarak lari untuk implementasi program cross country dilaksanakan menjadi empat tahapan. Tahap 1 yakni pertemuan 1 4 lari di alam terbuka dengan jarak $4 \mathrm{~km}$, tahap 2 yakni pertemuan 5 - 8 dengan jarak tempuh $6 \mathrm{~km}$, tahap 3 pada pertemuan 9 - 12 dengan jarak tempuh $8 \mathrm{~km}$, dan tahap 4 pertemuan 13 - 16 dengan jarak tempuh $10 \mathrm{~km}$.

Alat untuk mengukur tingkat kebugaran jasmani atlet adalah tes 2,4 km. Instrumen lari 2,4 km merupakan tes lari untuk mengukur tingkat kebugaran jasmani berdasarkan kriteria usia dan jenis kelamin (Bushman, 2017). Adapun administrasi pelaksanaan tes adalah sebagai berukut: 
1. Tujuan : mengukur tingkat kebugaran jasmani

2. Alat yang dibutuhkan : lintasan $\mathbf{4 0 0}$ meter dan stopwatch

3. Pelaksanaan: sasaran tes ini adalah menyelesaikan lari dalam track lintasan sepanjang 400 meter secepat mungkin dengan jumlah putaran sebanyak 6 putaran. Para peserta tes berada di garis start, ketika ada aba-aba "Ya" stopwatch dijalankan dan para peserta mulai berlari sesuai dengan kecepatan yang ditentukan masing-masing peserta. Meskipun jalan saja diperbolehkan, akan tetapi hal tersebut tidak dianjurkan.

4. Skoring : dicatat waktu menyelesaikan lari 1,5 mil / 2,4 km. 5. Norma : klasifikasi tingkat kebugaran tes lari 1,5 mil /2,4 km.

Tabel 2. Norma Kebugaran Jasmani 2,4 Km

\begin{tabular}{|c|c|c|c|c|c|}
\hline \multirow[b]{2}{*}{ Males } & \multicolumn{5}{|c|}{ Age } \\
\hline & 20 to 29 & 30 to 39 & 40 to 49 & 50 to 59 & 60 to 69 \\
\hline Superior & 66.3 or higher & 59.8 or higher & 55.6 or higher & 50.7 or higher & 43.0 or higher \\
\hline Excellent & 57.1 to 66.2 & 51.6 to 59.7 & 46.7 to 55.5 & 41.2 to 50.6 & 36.1 to 42.9 \\
\hline Good & 50.2 to 57.0 & 45.2 to 51.5 & 40.3 to 46.6 & 35.1 to 41.1 & 30.5 to 36.0 \\
\hline Fair & 44.9 to 50.1 & 39.6 to 45.1 & 35.7 to 40.2 & 30.7 to 35.0 & 26.6 to 30.4 \\
\hline Poor & 38.1 to 44.8 & 34.1 to 39.5 & 30.5 to 35.6 & 26.1 to 30.6 & 22.4 to 26.5 \\
\hline \multirow[t]{2}{*}{ Very poor } & 38.0 or lower & 34.0 or lower & 30.4 or lower & 26.0 or lower & 22.3 or lower \\
\hline & \multicolumn{5}{|c|}{ Age } \\
\hline Females & 20 to 29 & 30 to 39 & 40 to 49 & 50 to 59 & 60 to 69 \\
\hline Superior & 56.0 or higher & 45.8 or higher & 41.7 or higher & 35.9 or higher & 29.4 or higher \\
\hline Excellent & 46.5 to 55.9 & 37.5 to 45.6 & 34.0 to 41.6 & 28.6 to 35.8 & 24.6 to 29.3 \\
\hline Good & 40.6 to 46.4 & 32.2 to 37.4 & 28.7 to 39.9 & 25.2 to 28.5 & 21.2 to 24.5 \\
\hline Fair & 34.6 to 40.5 & 28.2 to 32.1 & 24.9 to 28.6 & 21.8 to 25.1 & 18.9 to 21.1 \\
\hline Poor & 28.6 to 34.5 & 24.1 to 28.1 & 21.3 to 24.8 & 19.1 to 21.7 & 16.5 to 18.8 \\
\hline Very poor & 28.5 or lower & 24.0 or lower & 21.2 or lower & 19.0 or lower & 16.4 or lower \\
\hline
\end{tabular}

Teknik analisis data penelitian ini melakukan uji prasyarat terlebih dahulu dengan uji normalitas kolmogorov smirnov dan uji homogenitas levene's test. Untuk uji hipotesis menggunakan uji paired sample t test (Gozali, 2013).

\section{HASIL}

Program treatment latihan crosss country yang dilakukan memberikan dampak yang signifikan terhadap tingkat kebugaran jasmani mahasiswa UKM Karate STKIP Muhammadiyah Kuningan. Hasil analisis dan pengolahan data bisa dilihat pada tabel di bawah ini. 
Oman Hadiana \& Sartono | Peningkatan Kebugaran Jasmani Mahasiswa UKM Karate STKIP Muhammadiyah Kuningan dimasa Pandemi Covis 19

Tabel 1. Hasil Pretest dan Posttest tingkat Kebugaran Jasmani Mahasiswa Putra UKM Karate STKIP Muhammadiyah Kunigan

\begin{tabular}{lcccccc}
\cline { 2 - 6 } & N & Minimum & Maximum & Sum & Mean & Std. Deviation \\
\hline Pretest Laki-Laki & 20 & 45,00 & 57,00 & 1000,00 & 50,0000 & 2,93795 \\
\hline Posttest Laki-Laki & 20 & 50,00 & 59,00 & 1076,00 & 53,8000 & 2,66754 \\
\hline Valid N (listwise) & 20 & & & & & \\
\hline
\end{tabular}

Berdasarkan tabel $1 \mathrm{di}$ atas hasil dari pretest kebugaran jasmani menggunakan tes lari 2,4 km diperoleh rata-rata skor 50 kategori cukup, sedangkan untuk hasil posttest diperoleh rata-rata skor 53,8 kategori baik. Data tersebut menunjukkan bahwa ada peningkatan hasil dari pretest ke posttest dengan menerapkan latihan crosss country terhadap peningkatan kebugaran jasmani mahasiswa putra yang terlibat dalam UKM Karate STKIP Muhammadiyah Kuningan. Data tigkat kebugaran jasmani mahasiswa putri dapat dilihat pada tabel 2 di bawah ini:

Tabel 2. Hasil Pretest dan Posttest tingkat Kebugaran Jasmani Mahasiswa Putra UKM Karate STKIP Muhammadiyah Kunigan

\begin{tabular}{lcccccc}
\cline { 2 - 6 } & N & Minimum & Maximum & Sum & Mean & Std. Deviation \\
\hline Pretest Perempuan & 16 & 35,00 & 45,00 & 626,00 & 39,1250 & 3,48090 \\
\hline Posttest Perempuan & 16 & 40,00 & 49,00 & 696,00 & 43,5000 & 3,01109 \\
\hline Valid N (listwise) & 16 & & & & & \\
\hline
\end{tabular}

Berdasarkan tabel 2 di atas hasil dari pretest kebugaran jasmani menggunakan tes lari 2,4 km diperoleh rata-rata skor 39,12 kategori cukup, sedangkan untuk hasil posttest diperoleh rata-rata skor 43,5 kategori baik. Data tersebut menunjukkan bahwa ada peningkatan hasil dari pretest ke posttest dengan menerapkan latihan crosss country terhadap peningkatan kebugaran jasmani mahasiswa putri yang terlibat dalam UKM Karate STKIP Muhammadiyah Kuningan. Hasil pengolahan data dari semua sampel menggunakan uji paired sample tes dapat di lihat pada tabel 3 di bawah ini:

Tabel 3. Hasil uji paired samples test

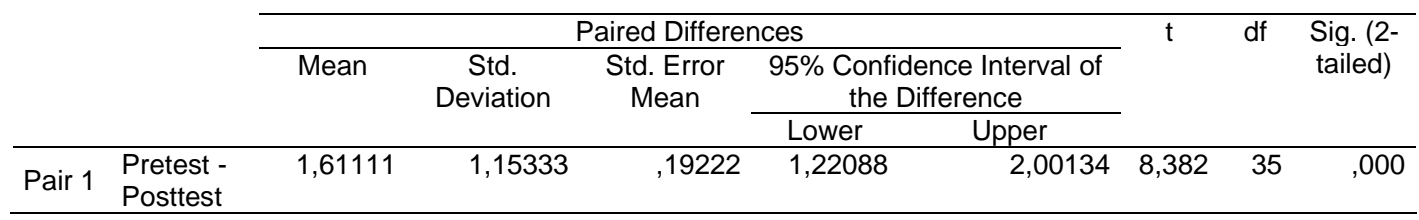

Hasil pengujian paired sample tes diketahui bahwa nilai sig. (2-tailed) sebesar 0.00 $<0.05$, maka disimpulkan bahwa terdapat perbedaan yang signifikan antara hasil tingkat kebugaran jasmani pada data pretest dan posttest, sehingga penerapan program latihan 
crosss country memberikan kontribusi dalam rangka meningkatkan kebugaran jasmani mahasiswa UKM Karate STKIP Muhammadiyah Kuningan.

\section{PEMBAHASAN}

Hasil analisis dan pengolahan data menunjukkan bahwa dengan menerapkan program latihan crosss country dapat meningkatkan tingkat kebugaran jasmani mahasiswa yang terlibat dalam UKM Karate di STKIP Muhammadiyah Kuningan. Kebugaran jasmani sendiri berarti kemampuan seseorang untuk melakukan aktivitas harian tanpa mengalami suatu kelelahan yang begitu bermakna (Avissa, et al., 2021; Kusnandar, et al., 2019; Listiandi, et al, 2020; Rozi, et al., 2021). Banyak faktor yang menjadikan tingkat kebugaran Mahasiswa IAIN Salatiga salah satunya adalah aktivitas fisik maupun olahraga yang kurang. Menurut Perry, salah satu faktor diantara beberapa faktor yang mempengaruhi tingkat kebugaran jasmani adalah kegiatan jasmaniah (aktivitas fisik) (Paryanto \& Wati, 2013). Pelaksanaan perkuliahan secara daring bagi Mahasiswa IAIN Salatiga disinyalir menjadi salah satu faktor yang menyebabkan keterlibatan aktivitas fisik menjadi kurang. Sedangkan faktor-faktor lain yang dapat mempengaruhi tingkat kebugaran seseorang adalah aktivitas fisik, indeks masa tubuh, dan kecemasan (Alamsyah, Hestiningsih, \& Saraswati, 2017). Hadirnya Pandemi Covid-19 memungkinkan timbulnya kecemasan pada Mahasiswa STKIP Muhammadiyah Kuningan yang berdampak terhadap kebugaran jasmaninya. Sumber lain menyebutkan bahwa kebugaran jasmani dapat dipengaruhi oleh usia, jenis kelamin, indeks masa tubuh, status merokok, tekanan darah, kadar hemoglobin dan aktivitas fisik (Nugraheni, 2013).

Hasil penelitian yang menunjukkan 75,8\% mahasiswa memiliki tingkat kebugaran kurang sekali perlu diperhatikan karena akan berpengaruh terhadap kesehatan, produktivitas, dan hasil belajarnya. Dengan olahraga akan meningkatkan kebugaran jasmani yang dapat menjaga derajat kesehatan. Untuk itu, Mahasiswa STKIP Muhammadiyah Kuningan perlu melakukan latihan olahraga yang terstruktur dan terukur untuk memiliki kebugaran yang baik. Latihan dan aktivitas olahraga yang teratut dapat menjaga kebugaran seseorang, bahkan sampai dengan lansia (Kurnianto, 2015). Seseorang dengan kebugaran jasmani yang baik hasil kerjanya kian produktif (Arifin, 2018). Mahasiswa UKM Karate STKIP Muhammadiyah Kuningan belum memiliki kebugaran jasmani baik akan terganggu produktivitasnya dalam mengikuti proses 
Oman Hadiana \& Sartono | Peningkatan Kebugaran Jasmani Mahasiswa UKM Karate STKIP Muhammadiyah Kuningan dimasa Pandemi Covis 19

perkuliahan. Penelitian tentang hubungan kebugaran terhadap hasil/prestasi belajar pada mahasiswa Tahap Persiapan Bersama (TPB) Institut Teknologi Bandung (ITB) menunjukkan hasil bahwa kebugaran secara simultan berpengaruh secara positif terhadap prestasi belajar mahasiswa (Sunadi, et al., 2018). Selanjutnya, pada masalah tingkat kebugaran Mahasiswa STKIP Muhammadiyah Kuningan ini dapat ditingkatkan dengan optimalisasi latihan kebugaran di rumah masing-masing dengan melaksanakan program yang sudah disusun.

\section{SIMPULAN}

Berdasarkan penjelasan yang sudah dipaparkan, penerapan program latihan croos country memberikan kontribusi yang signifikan dalam meningkatkan kebugaran jasmani mahasiswa UKM Karate STKIP Muhammadiyah Kuningan di masa pandemi covid 19. Hasil perolehan rata-rata skor kebugaran jasmani mahasiswa putra yang mengikuti UKM karate setelah diberikan program croos country sebesar 53,8 dengan kategori baik, sedangkan perolehan rata-rata skor kebugaran jasmani mahasiswa putri sebesar 43,5 dengan kategori baik. Penelitian selanjutnya berkaitan dengan program peningkatan kebugaran jasmani bisa dilakukan dengan bantuan teknologi berupa aplikasi dalam merekap hasil kebugaran, sehingga kategorisasi muncul secara digital.

\section{REFERENSI}

Aida, N, R. (2020, October 18). Pemerintah Sosialisasikan Aman, Iman, dan Imun Hadapi Covid-19, Apa Itu? Kompas. Com. Retrieved from https://www.kompas.com/tren/read/2020/10/18/133000765/pemerintahsosialisasikan aman-iman-dan-imun-hadapi-covid-19-apa-itu-?page=all

Amalia, L., Irwan, \& Hiola, F. (2020). Analisis Gejala Klinis dan Peningkatan Kekebalan Tubuh Untuk Mencegah Penyakit Covid-19. Jambura Journal of Health Sciences and Research, 2(2), 71-76. https://doi.org/10.35971/jjhsr.v2i2.6134

Amelia, N, A., Devy, H., Retno., \& Dian, S, L. (2017). Faktor-Faktor yang Berhubungan dengan Kebugaran Jasmani Pada Remaja Siswa Kelas XI SMK Negeri 11 Semarang. Jurnal Kesehatan Masyarakat, 5(3), 77-86.

Avissa, A., Kuswari, M., Nuzrina, R., Gifari, N., \& Melani, V. (2021). Pengaruh Program Latihan Olahraga dan Edukasi Gizi Terhadap Komposisi Tubuh, Lingkar Perut dan Lingkar Panggul pada Wanita Usia Produktif di Depok. Physical Activity Journal, 2(2), 176. https://doi.org/10.20884/1.paju.2021.2.2.3947 
Bachmann, J. M., DeFina, L. F., Franzini, L., Gao, A., Leonard, D. S., Cooper, K. H., Berry, J.D., \& Willis, B. L. (2015). Cardiorespiratory Fitness in Middle Age and Health Care Costs in Later Life. Journal of the American College of Cardiology, 66(17), 18761885.https://doi.org/10.1016/j.jacc.2015.08.030

Bile, R. L., \& Suharjana. (2019). Efektivitas Penggunaan Model Latihan Kebugaran “ BBC Exercise "Untuk Pemeliharaan Kebugaran Jasmani Mahasiswa. SPORTIVE: Journal of Physical Education, Sport and Recreation, 3(September), 30-37.

Budi, D. R. (2015). Pengaruh Modifikasi Permainan Vobas dan Kebugaran Jasmani Terhadap Peningkatan Kerjasama Siswa dalam Pembelajaran Penjas di SMP. Thesis. Retrieved from http://repository.upi.edu/id/eprint/17605

Bushman, Barbara. 2017. American College Sports Medicine: Complete Guide to Fitness \& Health. Human Kinetics.

Gumantan, A., Mahfud, I., \& Yuliandra, R. (2020). Pemberlakuan New Normal dan Pengetahuan. Sport Scienc and Education Journal, 1(2), 18-27.

Hale, R., Green, J., Hausselle, J., Saxby, D., \& Gonzalez, R. V. (2018). Quantified in vitro tibiofemoral contact during bodyweight back squats. Journal of Biomechanics, 79, 21 -30. https://doi.org/10.1016/j.jbiomech.2018.07.002

Harsono. (2012). Coaching dan Aspek-Aspek Psikologis dalam Coaching. Jakarta: CV. Irwan

Herlina, H, \& Suherman, M. (2020). Potensi Pembelajaran Pendidikan Jasmani Olahraga dan Kesehatan (Pjok) Di Tengah Pandemi Corona Virus Disease (Covid)-19 Di Sekolah Dasar. Tadulako Journal Sport Sciences And Physical Education, 8(1), 1-7.

Jatira, Y., \& Neviyarni, S. (2021). Fenomena Stress dan Pembiasaan Belajar Daring dimasa Pandemi Covid-19. Edukatif: Jurnal IImu Pendidikan, 3(1), 35-43.

Juniardi, E., Atiq, A., \& Purnomo, E. (2016). Survei Tingkat Volume Oksigen Maksimal (vo 2 max) Ekstrakurikuler Sepak Bola SMP 4 Sei. Nyirih. Jurnal Pendidikan Dan Pembelajaran Khatulistiwa, 5(2), 1-10.

Kim, J. K., Son, W. II, Sim, Y. J., Lee, J. S., \& Saud, K. O. (2020). The study of healthrelated fitness normative scores for nepalese older adults. International Journal of Environmental Research and Public Health, 17(8), $1-15$. https://doi.org/ 10.3390 /ijerph17082723

Knaeps, S., Bourgois, J. G., Charlier, R., Mertens, E., Lefevre, J., \& Wijndaele, K. (2016). Ten-year change in sedentary behaviour, moderate- to-vigorous physical activity , cardiorespiratory fitness and cardiometabolic risk: independent associations and mediation analysis. British Journal of Sports Medicine, 0 (August), 1 -7. https://doi.org/10.1136/bjsports-2016-096083 
Oman Hadiana \& Sartono | Peningkatan Kebugaran Jasmani Mahasiswa UKM Karate STKIP Muhammadiyah Kuningan dimasa Pandemi Covis 19

Kurnianto, D. (2015). Menjaga Kesehatan di Usia Lanjut. Jurnal Olahraga Prestasi, 11(2), 115182. https://doi.org/10.21831/jorpres.v11i2.5725

Kusnandar, Purnamasari, D. U., Nurcahyo, P. J., \& Darjito, E. (2019). Pengaruh Permainan Tradisional Banyumas Gol-Golan Terhadap Tingkat Kebugaran Jasmani Siswa Sekolah Dasar Di Kabupaten Banyumas. Physical Activity Journal (PAJU), 1(1), 18-26. https://doi.org/10.20884/1.paju.2019.1.1.1996

Lipecki, K., \& Rutowicz, B. (2015). The impact of ten weeks of bodyweight training on the level of physical fitness and selected parameters of body composition in women aged 21 -23 years. Pol. J. Sport Tourism 2015, 22, 64-73.

Listiandi, A. D., Budi, D. R., Suhartoyo, T., Hidayat, R., \& Bakhri, R. S. (2020). Healthy fitness zone: identification of body fat percentage, body mass index, and aerobic capacity for students. Jurnal SPORTIF : Jurnal Penelitian Pembelajaran, 6(3), 657673. https://doi.org/https://doi.org/10.29407/js_unpgri.v6i3.14936

Paryanto, R., \& Wati, I, D, P. (2013). Upaya Meningkatkan Kebugaran Jasmani Siswa Melalui Pendidikan Jasmani. Jurnal Pendidikan Dan Pembelajaran Untan, 2(5), 143 154.

Pratiwi, F, D. (2018). Tingkat kebugaran jasmani mahasiswa Jurusan Pendidikan Jasmani dan Kesehatan angkatan tahun 2014 FIK Universitas Negeri Malang (Universitas Negeri Malang). Retrieved from http://repository.um.ac.id/50591/

Rozi, F., Shidiq, A. P., Abdul, \& Rahman, Yanuar, A. (2021). Aspek Aman, Imun, dan Iman pada Pembelajaran Pendidikan Jasmani di IAIN Salatiga Selama Pandemi Covid-19 [The Aspects Of Safety, Immunity, and Faith in Physical Education Learning at IAIN Salatiga During The Covid-19 Pandemic]. Polyglot: Jurnal IImiah, 17(1), 145-158.

Setiyawan., Kresnapati, P., \& Setiawan, D. A. (2020). Analisis perkuliahan daring mahasiswa PJKR Universitas PGRI Semarang sebagai dampak pandemi covid 19. Edu Sportivo:Indonesian Journal of Physical Education, 1(1), 25-32. https://doi.org/10.25299/es:ijope.2020.vol1(1).5148.

Suhartoyo, T., Budi, D. R., Kusuma, M. N. H., Syafei, M., Listiandi, A. D., \& Hidayat, R. (2019). Identifikasi Kebugaran Jasmani Siswa SMP Di Daerah Dataran Tinggi Kabupaten Banyumas. Physical Activity Journal. https://doi.org/10.20884/1.paju.2019.1.1.1995

Sunadi, D., Soemardji, A., Apriantono, T., \& Komar, R. W. (2018). Tingkat Kebugaran dan Prestasi Belajar. Jurnal Sosioteknologi, 17(2), 326-366. https://doi.org/10.5614/ sostek.itbj.2018.17.2.14

Supriyadi, A., \& Dupri. (2020). Peningkatan hasil belajar bolavoli dengan menggunakan sistem daring. Edu Sportivo: Indonesian Journal of Physical Education, 1(2), 112119. https://doi.org/10.25299/es:ijope.2020.vol1(2).5609 
Tapo, Y. B. O., \& Bile, R. L. (2020). Efektivitas penggunaan model latihan olahraga pernapasan MONACORS untuk pemeliharaan kesehatan fungsi paru bagi mahasiswa dalam menghadapi pandemi COVID-19. Ejurnal IMEDTECH, 4(2), 5465. 